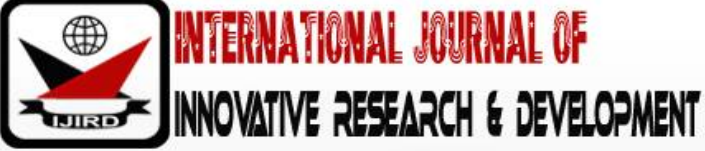

ISSN 2278 - 0211 (Online)

\section{Attitude and Perception of Family Planning Among Rural Couples in Rural Parts of Nigeria: A Study of Danmusa Local Government Area of Katsina State, Nigeria}

\begin{tabular}{c} 
Anifat Abdurraheem \\
Lecturer, Department of Sociology, Federal University Dutsinma-Ma, Nigeria \\
Ilim Moses Msughter \\
Lecturer, Department of Sociology, Federal University Dutsin-Ma, Nigeria \\
Amali Suleiman \\
Lecturer, Department of Sociology, Federal University Dutsin-Ma, Nigeria \\
\hline
\end{tabular}

\begin{abstract}
:
The main goal of the study was to investigate the people's knowledge, attitude and perception towards family planning practices in Danmusa local government area of Katsina state. The study was therefore built around the following specific objectives as thus; To assess the level of awareness on family planning among couples in Danmusa local government area, to find out the types and nature of family planning practices in Danmusa local government area, to identify the perception of couples towards family planning Danmusa local government area, to identify the factors or challenges that influence couples perception of family planning in Danmusa Local Government area and to find out ways to encourage positive attitude towards family planning. The study utilized both primary and secondary data. A cluster and random sampling techniques were used to sample the opinion of 305 respondents across the 11 districts of Dan Musa local government. Both secondary and primary data were used for analyses and the analyses were done quantitatively and qualitatively. The data were presented in frequency distribution table and some of the variables that provided more insight with regards to realising the objectives of the study were cross tabulated to give further clarity and depth to the connection between the variables. The study found out that the level of awareness of family planning in Danmusa local government is high, but the people prefer traditional methods. The study also discovered that, the couples' skepticism towards modern family planning is influenced by religion and level of education. In other words, religion, gender and level of education were discovered to be major factors that determine couples' attitude, knowledge and perception towards family planning in Dan Musa local government area. The study therefore recommends that education needs to be intensified among the rural people to illicit positive attitude towards family planning from them, and that intensive campaigns and awareness need to be embark upon by government and non-governmental agencies. Also training of health workers and improvement on the old family planning techniques need to be done to make them safer, cheaper, effective and easily accessible.
\end{abstract}

Keywords: Perception, planning, child spacing, and contraceptives

\section{Introduction}

The family is the building block of society. It is a nursery, a school, a hospital, a leisure place, a place of refuge and a place of rest; it encompasses the whole of society. It fashions beliefs as well as a place for individuals for the rest of their lives. (Abbot and Wallace,1992:131).Certain functions are basic to all types of families namely: those of reproduction, socialization of the young, economic and emotional support to family members. This is invariably linked to the contemporary issue of family planning. The family becomes an important institution in the sense that it provides the platform for success and failure of its members. Planning and child spacing thus helps family members to realized their potentials and aspirations in the society. Family planning is an organized effort essentially to ensure that couples who want to limit their family size or to space their children have access to contraceptive information and services needed (Isiugo-Abaniher, 1996). According to Netty et al (2015) fertility and future projected population growth are very high in sub-Saharan Africa than in any other region of the world. Furthermore, the population growth rate is of major international concern because it has the potential to hinder attainment of health and other development goals in the subregion.

Family planning is thus aim at empowering individuals and couples to anticipate and attain their desired number of children whilst appropriately spacing and timing their births. Onigbende (2010) also averred that family planning can prevent between $20 \%$ and $35 \%$ of maternal deaths. However, limited access to family planning pills, knowledge, facilities as well as cultural values that sanctions large family sizes in Africa and other developing countries prevent correct and consistent use of family planning in most low and middle income countries. An estimated 215 million women in the 
developing world have an unmet need for modern contraception (Azmat 2012). The survey indicates that use of modern contraceptive methods among currently married women in developing countries is $22 \%$; whereas the use of contraception is even lower among rural residents (17.7\%) and among women with low levels of education. In Nigeria a report from the National AIDS and Reproductive Health Survey (NARHS),( 2012) indicated that while awareness of contraceptive was high in Western countries like England, France, Italy and Germany, the proportion of females using any method and a modern method of contraception particularly in rural communities was $13 \%$. The methods of modern contraceptives available at the regional and national levels include: pills, intrauterine contraceptive device, injectables, implants, male condom, female condom, male and female sterilization, diaphragm among others. Awolabi (2015) identified, poor awareness, limited number of health workers as well as accessibility of family planning techniques as the major challenges that results to poor negative perception of the practice among rural dwellers.

The Nigerian government has been spending large sum of money annually through the Federal Ministry of Health on public campaigns for family planning services and some private non-governmental organizations also provide clinical services and public enlightenment campaigns on the importance of family planning. According to Ofonime and Ekong (2015) the common modern family methods available include: pills, intrauterine contraceptive device, injectables, implants, male condom, female condom, male and female sterilization, diaphragm, foam/jelly, lactational ammenorrhoea and emergency contraception. However, available statistics have shown that women have negative perception towards family planning. According to the Nigerian Demographic and health Survey, 2013 (NDHS), about 23\% of teenage girls between age 15 and 19 years were already mothers or pregnant with their first child. About 250 out of 1000 adolescent pregnancies in Nigeria end in unsafe abortion and of the estimated 600,000 induced abortions annually, adolescents contribute $60 \%$. Of onime and Ekong (2015) similarly avers that the urban dwellers are reported to have greater access and higher chances of utilizing family planning methods. The rural communities, which contribute about $70 \%$ of Nigeria's population, have very high fertility rate and a low knowledge and negative attitude towards family planning. A study of rural communities South Western Nigeria reported the point prevalence of contraceptive use among rural women to be as low as $33.3 \%$. One of the factors influencing utilization and perception is level of education and accessibility. An empirical study to assess the attitude and knowledge of family planning among rural women in Danmusa-East local has thus become imperative to assess the challenges that influence couple's perception of family planning.

\subsection{Statement of Problems}

Traditionally, African culture and values placed high premium on large family sizes; this is because a large family in a rural set up means social security and more hands to till land. The family was consequently regarded as the unit of production that provided. Industrialization led to the emergence of the factory system, where shop and office have since then replaced the family as a unit of production. Large family is no longer required to till land. Accordingly, modern societies continuously discourage large family size with its concomitant socio-economic consequences of over-population. According to Igbo (2003) family prosperity and economic comfort is a function of amount of education and specialized skill possessed by members of and not necessarily the number of children born to a family. On the strength of this view point, one highly educated employed member of a family alone can support the family much better than a dozen unemployed illiterate can. Despite this, some traditional societies in Africa still celebrate large families.

However, households with many children are more likely, overtime, to become poor and less likely to recover from poverty than families with only few children. Furthermore, children from large families are usually less wellnourished and less well educated than those from smaller families. Moreover, a woman's inability to space her pregnancies has a direct impact on her physical health/well-being and on the outcome of subsequent pregnancy. Lack of or family planning denies the woman the woman the stamina for another pregnancy, denies the family a little breathing space with regards to family budgeting and most importantly.

Recent studies; Olaiton (2011), Chigozie O, Precious, Uchenna , and Godswill (2015) as well as Omishakin (2015) conducted on the subject of family planning in Nigeria revealed an increase in knowledge and attitude towards family planning in urban centers. In most rural communities however, the attitude and perception towards family planning is not encouraging as in urban centers. In their study of "knowledge, attitude and practice of family planning among women in rural communities in Southern Nigeria "for instance, Ofonime and Ikobong (2015) submitted that the awareness and knowledge of family planning techniques in remote parts of Nigeria is poor. This might be as a result of poor access to family planning services, lack of awareness, and cultural influence of ethnic some groups regarding. It is based on this that a study of a predominantly rural area like the communities in Danmusa local government becomes necessary to highlight the challenges that influence their perception and attitude towards family planning in order to bridge the literature on the subject with reference to rural communities.

\subsection{Aims and Objective of the Study}

The major objective of this study is to investigate the attitude, knowledge and perception of family planning among couples in Danmusa Local Government Area of Katsina state.

The specific research objectives include:

- To assess the level of awareness on family planning among couples in Danmusa Local Government Area.

- $\quad$ To find out the types and nature of family planning practiced in Danmusa Local Government Area.

- To identify the perception of couples towards family planning Danmusa Local Government Area.

- To identify the factors that influence couples perception of family planning in Danmusa Local Government Area.

- To find out ways to foster positive attitude towards family planning. 


\subsection{About the Study Area}

Dan-musa Local Government Area was initially created during the second Republic (1979-1983). It was created by then Kaduna State Government led by Alh. Abba Musa Rimi. At that time, Danmusa Local Government was carved out of the old Dutsin-ma Local Government.The approximate area of Danmusa Local Government is about seven hundred and sixty (760 sq km) square kilometers. 'Yantumaki District, which is one of the two Districts in the Local Government Area, is among the largest District Areas in Katsina Emirate. The population of the area according to the 2006 Census is 117,285 for 'Yantumaki district and 44,367 for Danmusa district. So the estimated population figure of Danmusa local government is 161,652 .

The then Head of State, Gen. Sani Abacha eventually set up a committee to receive complains and requests for the creation of more states and Local Government Areas and boundary adjustments. At that time also, the then national Constitutional Conference set up another committee for that purpose.The outcome of these efforts was the creation of more state and Local Government Areas across the Nigerian Federation. Danmusa was one of those Local Government Areas created in Katsina State in 1996. The Local Government Area at creation and up to present day comprises two district Areas i.e. Danmusa District Area and 'Yantumaki District Area. These two Districts between them were made up of several villages and communities with a common boundary with a Zamfara State in the Western part of the Local Government.

Majority of the inhabitants of the local government are Muslims and agriculture is their main occupation. Over $92 \%$ of the entire population engages in one agricultural activity or another, such as crop production, animal rearing, irrigation, etc. There is hardly any crop that is not cultivated in the area, ranging from cash crop such as cotton, groundnut, soya beans and sugarcane to food crop such guinea corn, millet, beans, maize, cassava, etc. The Area is also blessed with a lot of resources. The area equally has a very large forts reserve which accommodates various species of animals, plants and shrubs. Of significant to this, is the presence of large number of Fulani nomads who ensure constant supply of meat, milk, hides and skin and a lot of other animal product. Danmusa is also home to several types of solid minerals, such as kaolin, iron-ore, silica, precious stones, etc. These are also potential raw materials for small scale industries. The area is investment friendly, because it is one of the most peaceful and fertile areas in the whole of Katsina State.

\section{Methodology of the Study}

The study is aim at assessing people's knowledge and perception towards family planning. Itis therefore interested in people's opinion and attitude. The survey research design is therefore considered an appropriate research design for the study. This is because it allows the researcher to make use of sample population as representative of the total population.

The population of the study includes men and women in Danmusa local government who are married and residing in Danmusa local government area at the time of conducting this research. The criteria for selection therefore means that the respondents must be married and to be able to air their opinion regarding the use of contraception and family planning. A total of 399 people were thus supposed to be initially contacted for information regarding the topic, however, only 305 were used.

Regarding the techniques and method of data collection, the study made use of both questionnaires and interview to gather data from over 305 respondents. Similarly, the study adopted a multi-stage sampling procedure. In the first stage, the researcher will use the cluster sampling procedure to divide Danmusa local government into two major districts (Danmusa and Yantumaki) as clusters. Cluster sampling technique is recommended when elements in the studied population are scattered or spread over very large area and there are sufficient reasons to believe that the population can be grouped into smaller units or clusters (Akintoye and Otite 1994). Respondents were drawn from the following places; Unguwar Bandella. Mai Dabino 'A', Yantumaki 'B', Dandire 'A', Mara, Dan Alkima, Dan Ali and Dan Musa'B'. In selecting the respondents, simple random sampling was used and balloting technique was used to pick the names of households visited for information regarding attitude and perception of family planning.

Data analysis plays a very crucial role in any social research. For this research, data collected from the field wereanalyzed both qualitatively and quantitatively using simple tables and percentages.

\section{Data Presentation, Analyses and Discussion of Findings}

\subsection{Introduction}

This section deals primarily with the analyses of data gathered from both secondary and primary sources. The data is presented in simple percentage and frequency table for easy understanding. The analysis is done in with reference to related literature regarding the variable in question.

\subsection{Fertility Trends and Population Structure of Nigeria}

The current Nigerian population is estimated at 178,571,721 people (World Population Review, 2014). This makes the country the most populous on the continent of Africa and the seventh most populous nation in the world. Nigeria has experienced a population explosion for the last 50 years due to very high fertility rates, quadrupling its population during this time. Growth was fastest in the 1980s, after child mortality had dropped sharply, and has slowed slightly since then as the birth rate has sunk slightly. According to the 2012 revision of the World Population Prospects, the total population was 159,708,000 in 2010, compared to only 37,860,000 in 1950. The proportion of children below the age of 15 in 2010 was $44.0 \%, 53.2 \%$ was between 15 and 65 years of age, while $2.7 \%$ was 65 years or older. According to the United Nations, the population of Nigeria will reach 440 million by 2050. Nigeria will then be the third most populous 
country in the world. In 2100, the population of Nigeria will reach 914 million. The table below illustrates the fertility trends in Nigeria from 1950 to 2015.

\begin{tabular}{|c|c|c|c|c|c|c|c|c|}
\hline Period & $\begin{array}{c}\text { Live Births } \\
\text { Per Year }\end{array}$ & $\begin{array}{c}\text { Deaths } \\
\text { Per Year }\end{array}$ & $\begin{array}{c}\text { Natural Change } \\
\text { Per Year }\end{array}$ & CBR & CDR & NC & TFR & IMR \\
\hline $1950-1955$ & 1821000 & 1169000 & 652000 & 46.1 & 29.6 & 16.5 & 6.35 & 200.7 \\
\hline $1955-1960$ & 1998000 & 1181000 & 817000 & 46.3 & 27.3 & 19.0 & 6.35 & 186.6 \\
\hline $1960-1965$ & 2202000 & 1197000 & 1005000 & 46.1 & 25.1 & 21.0 & 6.35 & 172.9 \\
\hline $1965-1970$ & 2431000 & 1244000 & 1187000 & 45.7 & 23.4 & 22.3 & 6.35 & 159.6 \\
\hline $1970-1975$ & 2801000 & 1306000 & 1495000 & 46.8 & 21.8 & 25.0 & 6.61 & 147.3 \\
\hline $1975-1980$ & 3232000 & 1377000 & 1855000 & 47.1 & 20.1 & 27.0 & 6.76 & 134.2 \\
\hline $1980-1985$ & 3642000 & 1467000 & 2175000 & 46.2 & 18.6 & 27.6 & 6.76 & 125.3 \\
\hline $1985-1990$ & 4018000 & 1657000 & 2361000 & 44.8 & 18.5 & 26.3 & 6.60 & 126.0 \\
\hline $1990-1995$ & 4446000 & 1866000 & 2580000 & 43.6 & 18.3 & 25.3 & 6.37 & 126.0 \\
\hline $1995-2000$ & 4984000 & 2075000 & 2909000 & 43.1 & 17.9 & 25.2 & 6.17 & 118.6 \\
\hline $2000-2005$ & 5606000 & 2230000 & 3376000 & 42.7 & 17.0 & 25.7 & 6.05 & 104.0 \\
\hline $2005-2010$ & 6309000 & 2224000 & 4085000 & 42.2 & 14.9 & 27.3 & 6.00 & 89.9 \\
\hline $2010-2015$ & 7117000 & 2294000 & 4823000 & 41.5 & 13.4 & 28.1 & 6.00 & 76.3 \\
\hline
\end{tabular}

Table 1: Fertility Trend in Nigeria (1950-2015)

Source: United Nations Population Department (2012)

Key: CDR=Crude Birth Rate (Per 1000); CDR=Crude Death

Rate (Per 1000); NC=Natural Change (Per 1000); IMR=Infant

Mortality Rate (Per 1000 Live Births); TFR=Total Fertility Rate

As can be seen from the above table, fertility in Nigeria has been on the increase leading to rapid population growth in the country. Based on the trend, the United Nations Population Department (2012), projected that 711700 children would have been born between 2010 and 2015. Crude birth rate in the country is estimated at about 41.5 children per 1000 women of reproductive age, while an average woman is expected to deliver six children in her reproductive. The country's population is growing at the rate of 2.54 percent. These figures are high compared to the United States of America where the crude birth rate is 12.6 children per 1000 women of reproductive age and an average woman is expected to deliver about two children (Muhammed, 2009).

Another noticeable trend in Nigeria fertility structure is the high prevalence of teenage pregnancies. According to the Federal Ministry of Health (2001), teenage pregnancies pose serious reproductive health challenge since it accounts for about 70 percent of maternal mortality due to high-risk pregnancies, unsafe abortion or delivery complications. Studies have shown that most young girls engage in unprotected sexual intercourse on the mistaken belief that they are too young to get pregnant (Lowe \& Radius, 1987; Furstenberg, 1976). This has led to many unwanted and unplanned pregnancies.

A Very important trend which is related to the problem of the study is low child spacing. According to Apav-Igba (2015) this is another remarkable trend in fertility structure of Nigeria. An average Nigerian woman typically gives birth to six children in her reproductive life (UNPD, 2012). Exceptional cases have been found where some women have given birth to more than ten children (Thomas, 1995)and these are delivered at intervals of about 18 months or less. This is poor child spacing since it does not conform to accepted standard of at least two years, and has remarkable implications for reproduction health of the woman. The problem is compounded by the fact that African (Nigerian) women have especially longer reproductive life (15-49 years) than the normal 15-44 year bracket in the Western world. But the question is what are the social and cultural influence on the current fertility trend in Nigeria?

\subsection{Socio-Demographic Variables}

This section deals with the presentation and analyses of socio-demographic variables of the respondents particularly those that have significant influence on the result and determine conclusion of the study. The sociodemographic variables of respondents covered by the study include: sex, age, marital status, religious affiliations, occupation, educational level, and number of children.

The information in table 2below indicates the distribution of respondents according to socio-demographic characteristics. The data reveals that $61.3 \%$ (187) respondents were men, while $38 \%$ (118) were women. This indicated that majority of the respondents used for this study were men. With reference to age distribution of the respondents, the table indicated that, the age bracket of 26-45 years constituted majority of the respondents with $51.8 \%$ (158). People who are within the age bracket of 25-below made up 16.4\% (50), while those between 46 and above years of age constituted $31.8 \%$ (117) of the sampled population. Also, the data on the same table reveal that those who were married made up 81.9.\% (250) of the respondents. 1.6\% (5) of the respondents were divorced, while 16.4\% (50) of them were separated. This indicate that majority of the sampled population were married.

Similarly, the data collected on religious affiliation of the respondents shows that $81.9 \%$ (250) of the respondents were Muslims, while 9.8\% (30) were Christians. An insignificant number; $4.9 \%$ (25) also indicated that they belong to neither Christianity nor Islamic religion. Majority of the sample population with were thus Christians. With regards to educational level, the information indicated that 39.0\% (119) of the respondents attained primary level of education, while majority (54.8\%) of the respondents acquired secondary level of education and a few (6.2) have tertiary level of education. Finally, 
the table revealed that majority (48.9\%) of the respondents had between $4-7$ children while only a few (34.4\%) had between 1-3 children.

\begin{tabular}{|c|c|c|}
\hline Variables & Frequency (f) & Percentage (\%) \\
\hline \multicolumn{3}{|l|}{ Sex } \\
\hline Male & 201 & 53.6 \\
\hline Female & 174 & 46.4 \\
\hline Total & 375 & 100 \\
\hline \multicolumn{3}{|l|}{ B: Age } \\
\hline $18-30$ & 40 & 10.7 \\
\hline $31-35$ & 171 & 45.6 \\
\hline 36 and above & 164 & 43.7 \\
\hline Total & 375 & 100 \\
\hline \multicolumn{3}{|l|}{ C: Marital Status } \\
\hline Single & 181 & 48.3 \\
\hline Married & 190 & 31.5 \\
\hline Others & 4 & 50.7 \\
\hline Total & 375 & 100 \\
\hline \multicolumn{3}{|l|}{ D: Religious Affiliation } \\
\hline Christianity & 90 & 24 \\
\hline Islam & 277 & 73.9 \\
\hline Others & 8 & 2.1 \\
\hline Total & 375 & 100 \\
\hline \multicolumn{3}{|c|}{ E: Educational Qualification } \\
\hline Primary Level & 203 & 54.1 \\
\hline Secondary Level & 98 & 26.1 \\
\hline Tertiary Level & 30 & 8 \\
\hline Others & 44 & 11 \\
\hline Total & 375 & 100 \\
\hline \multicolumn{3}{|l|}{ F: Occupation } \\
\hline Farmers & 167 & 44.5 \\
\hline Traders & 106 & 28.3 \\
\hline Civil/ Public Servants & 60 & 16 \\
\hline Others & 42 & 11.2 \\
\hline
\end{tabular}

Table 2: Showing Socio-Demographic Attributes of the Respondents Source: Field survey 2017

\begin{tabular}{|c|c|c|}
\hline Response & Frequency (F) & Percentage (\%) \\
\hline Yes & 229 & 75.1 \\
\hline No & 64 & 20.0 \\
\hline Don't Know & 12 & 3.9 \\
\hline Total & 305 & 100 \\
\hline
\end{tabular}

Table 3: Distribution of Respondents According to Whether They Are Aware of Family Planning Practice in Danmusa Local Government Area Source: Field Survey 2017

The data displayed in table 3 revealed that majority (75.1\%) express knowledge of family planning practices. $20.9 \%$ of the respondent on the other hand, denied knowledge while 3.2\% of them were uncertain on the issue. Interview with some of the elderly people and health care providers in the area revealed that almost all the primary health care centers in the localities visited have family planning services couples usually on offer for women from the day they are pregnant through ante-natal services through post-natal period and any other time they are interested in accessing family planning services or information.

\begin{tabular}{|c|c|c|}
\hline Response & Frequency (F) & Percentage (\%) \\
\hline High & 131 & 42.9 \\
\hline Moderate & 107 & 35.1 \\
\hline Low & 67 & 21.0 \\
\hline Total & 305 & 100 \\
\hline
\end{tabular}

Table 4: Distribution of Respondents According to Their Level of Awareness of Family Planning Practice in Danmusa Local Government Area Source: Field Survey 2017 
The information on table 4above reveal that majority (42.9\%) of the respondents concurred that the level of awareness of family planning is high, $35.1 \%$ of them said, it is moderate while $21.0 \%$ of the respondents agreed that the level of corruption is low. This implies that knowledge of family planning practice is high even in the rural areas. Similarly the posters and fliers advertising different form of modern family planning and contraceptives to be adopted on the wall of most of the primary health centers visited corroborated this assertion that the awareness of family planning is indeed high.

\begin{tabular}{|c|c|c|}
\hline Family Planning Methods & Frequency (F) & Percentage (\%) \\
\hline Traditional Methods & 139 & 45.6 \\
\hline Modern Methods & 89 & 29.1 \\
\hline Others & 77 & 25.2 \\
\hline Total & 305 & 100 \\
\hline
\end{tabular}

Table 5: Distribution of Respondents According to Common Family

Planning Methods in Danmusa Local Government Area

Source: Field Survey 2017

The data in table 5 indicated that majority $(45.6 \%)$ of the population agreed that traditional family planning methods are more common in their area, while $29.1 \%$ said modern family planning methods are more common in their area; and $25.2 \%$ indicated that their other forms of family planning methods that couples utilized apart from the traditional and the modern methods. The result of the interview also supports data from the questionnaire. Most of the health workers interviewed revealed that couple in Danmusa local government hardly utilized modern family planning contraceptives like pills and Condoms. One of the health officials submitted thus: even though condoms are always available in our facilities, there is low demand for condom couples. In earlier studies, Omishakin (2015) concluded that transportation and globalization have made access and knowledge of modern contraceptives accessible, remote parts of Nigeria are still resisting them. Explaining their apathy towards modern contraceptives, a woman in Unguwar Kanawa village submitted thus: taking pills or using protection with your husband is immoral and against doctrines of Islam. This explains the high birthrate among couple in the Northern part of the country where this study was conducted.

\begin{tabular}{|c|c|c|}
\hline Factors to Consider & Frequency (F) & Percentage (\%) \\
\hline Money & 76 & 24.9 \\
\hline Knowledge of each Method & 149 & 48.9 \\
\hline Accessibility & 81 & 26.6 \\
\hline Total & 305 & 100 \\
\hline
\end{tabular}

Table 6: Distribution of Respondents According to Factors That

Influences Type of Family Planning Practice to Choose from

Source: Field Survey 2017

Table 6 contains information regarding factors that determines which methods of family methods to be adopted by couples. The data revealed that a good number (48.9\%) of the respondents considered knowledge of each of the family planning methods as a major determining factor regarding the decision of which method of family planning to go for by couples. Others; $26.6 \%$ and $24.9 \%$ considered accessibility to the methods and money respectively as determining factor. In a related study, Olaitan (2009) after an empirical study of factors that determine the choice of contraceptive agreed that all the above factors (Knowledge, accessibility and cost) play an important part in decision of which method of contraceptive to use. She however added that other factors like health risk and permanence as well as effectiveness are also considered by couples.

\begin{tabular}{|c|c|c|c|}
\hline Attitudes Towards & \multicolumn{2}{|c|}{ Sex } & N \\
F/ Planning & Male (\%) & Female (\%) & \\
\hline Positive & $130(42.6)$ & $19(6.2)$ & 149 \\
Negative & $43(13.1)$ & $77(25.2)$ & 120 \\
Indifferent & $24(7.9)$ & $12(3.9)$ & 36 \\
\hline Total & $197(100)$ & $108(100)$ & 305 \\
\hline
\end{tabular}

Table 7: Distribution of Attitude towards Family Planning Practices According to Gender

Source: Field Survey, 2015

Table 7 contains information regarding the influence of gender on attitude towards family practice in Danmusa local government area. It is observed that $42.6 \%$ (130) of male respondents have positive attitude towards family planning, while only a few of them were indifferent to the issue and $13.1 \%$ of them have negative attitude towards family planning. This implies that majority of the sampled population of men for this study express positive attitude towards family planning as compared to majority of women; $25.2 \%$ who express having negative attitude towards family planning. In other words, while men like family planning, women dislike it. Only $6.2 \%$ of women express having positive attitude towards family planning. Providing further empirical backing to this, Akinwalere, Owolabi\& Adesida (2015) submitted that, while women are the career and usually suffer the failure of most family planning methods, the men are hardly 
cooperative when it comes to issues of contraceptive particularly if it stands in their way of denying them sexual pleasure. It is therefore more likely for women to express dislike of family planning.

\begin{tabular}{|c|c|c|}
\hline Factors & Frequency (F) & Percentage (\%) \\
\hline Religion & 181 & 59.3 \\
\hline Culture & 31 & 10.2 \\
\hline Education & 93 & 30.5 \\
\hline Total & 305 & 100 \\
\hline
\end{tabular}

Table 8: Distribution of Respondents According to Major Factors That

Influence Attitude and Perception towards Family Planning in Danmusa Local Government Area

Source: Field Survey 2017

The data in table 8 revealed that education is the major factor that influence attitude towards family planning in Danmusa local government. This is because majority (59.3\%) of respondents agreed that religious values influence decisions and attitude towards family planning. $10.2 \%$ of the respondents however, set aside culture as a major factor and a few (30.5\%) locate education as determining attitude and decision regarding family planning.

\begin{tabular}{|c|c|c|c|c|}
\hline \multicolumn{2}{|c|}{ Religion } & \multicolumn{2}{c|}{ Perception towards Family Planning } & \multirow{2}{*}{ N } \\
\cline { 1 - 3 } \multicolumn{2}{|c|}{ Yes \% } & No \% & Not Sure \% & \\
\hline Islam & $141(46.2)$ & $75(24.2)$ & $14(4.5)$ & 230 \\
\hline Christianity & $15(4.9)$ & $10(3.3)$ & $25(8.2)$ & 50 \\
\hline Others & $2(0.1)$ & $4(3.7)$ & $19(6.2)$ & 25 \\
\hline Total & $158(100)$ & $89(100)$ & $58(100)$ & 305 \\
\hline
\end{tabular}

Table 9: Religious Affiliation and Perception towards Family

Planning Among Couple in Danmusa Local Government Area Field Survey 2017

The data in table 9 shows that, a significant number (46.2\%) of the sampled population who are Muslims agreed that religious values influenced attitudes and perception towards family planning. Similarly, a significant number (8.2\%) of the sampled Christian population were not sure whether religious values influence attitudes towards family planning. This position agreed with argument by Suleiman (2011) who submitted that Islamic doctrines which encourage polygamous marriage sanctions and legitimizes large family size and hence frown at anything that's stand in the way of realizing this injunction.

\begin{tabular}{|c|c|c|c|c|}
\hline \multirow{2}{*}{ Education } & \multirow{2}{*}{ Yes \% } & \multicolumn{2}{|c|}{ Perception Towards Family Planning } & \multirow{2}{*}{ N } \\
\cline { 3 - 4 } & $76(24.9)$ & No \% & Not Sure & \\
\hline Primary & $128(41.9)$ & $33(10.8)$ & $10(3.3)$ & 119 \\
\hline Secondary & $20(6.6)$ & $15(4.9)$ & $4(1.3)$ & 147 \\
\hline Tertiary & $224(100)$ & $61(100)$ & $6(1.0)$ & 39 \\
\hline Total & & $20(100)$ & 305 \\
\hline
\end{tabular}

Table 10: Educational Level and Perception towards Family Planning Field Survey 2017

Table 10 shows that, majority (24.9\%) of respondents who indicate having primary level of education agreed that education influence perception and attitudes towards family planning among couple. Similarly, significant number of those who indicated having secondary level education also agreed that education influence attitude towards family planning. In the same manner, a good number (6.6\%) of those who identified themselves as acquiring tertiary level of education also agreed with this stand. This implies that, education or lack of it can determine attitude and perception towards family planning among couple. In earlier studies, Apav-Igba \& Ilim (2015) submitted that ignorance and illiteracy significantly influence attitude and perception towards family planning among rural people. In other words, the more educated couples are, the more likelihood that they will embrace and use contraceptive, and vice versa if the couple are less educated.

\begin{tabular}{|c|c|c|}
\hline Effects on National Development & Frequency (F) & Percentage (\%) \\
\hline More awareness & 96 & 31.5 \\
\hline Cheaper pills & 41 & 13.4 \\
\hline Training of Health Workers & 119 & 39.0 \\
\hline Proper counseling & 59 & 19.3 \\
Total & 305 & 100 \\
\hline
\end{tabular}

Table 11: Distribution of Respondents According to Strategies to Be Adapted to Make Family Planning Services Easily Accessible and Affordable

Source: Field Survey 2017 
Table 11 above contains information gathered from the respondents regarding strategies to be adopted to ensure affordable and accessible family planning services. The data revealed that majority (39.0\%) of the respondents suggested that health workers who are in charge of delivering family planning services should be trained on how and when to use which method of family planning. Similarly, others i.e. 31.5\% of the respondents advocated for creation of more awareness by the government. A few (19.3\%), of the respondents however advised that cheaper contraceptive methods be made available at the local level.

\section{Discussion of Findings}

This section is concern with discussion of the major findings of the study. To ensure easy understanding and see if the study has been able to realized its objectives hence give the work the academic standard it deserves, the findings are discussed according to the objectives of the study earlier stated in chapter one of the study. Related literature on each of the variable or finding will also be explored to provide clarity and further interrogate the findings from the field. The objectives of the study will be re-stated below.

The first objective of the study is aim at assessing the level of awareness on family planning among couples in Danmusa local government area. Then finding regarding this objective as presented in table 3 and 4 indicate that the people of Danmusa local government are indeed aware of family planning practices. Table 4 further indicates the level of awareness which is high among the sampled population. In a similar study, Omishakin (2015) corroborate this when she revealed in a study of rural communities in Oshogbo local government area of Osun state that a good number (98\%) knew about family planning while about $44 \%$ of them knew all the methods listed in the questionnaire, implying that family planning methods and practices have permeated the rural communities in Nigeria.

The second objective of the study is concern with finding out the types and nature of family planning practices in Danmusa Local Government Area. The findings on this revealed that, the people of Danmusa local government are more inclined to using traditional family planning methods. The result from questionnaire (see table 5) and interview revealed that the people fancy traditional methods due to ignorance of potency of modern methods and religious values. Table 6 also contains a useful discovery where it revealed that the knowledge of which method of contraceptive to use is considered the primary concern for women when contemplating which methods of family planning to adopt. The result of the interview (as transcribed) also revealed that condoms are particularly not popular with the couples in Danmusa local government.

The third objective is to identify the perception of couples towards family planning in Danmusa Local Government Area. The study discovered connection between Gender and attitude towards family planning. The data in table 6 indicate that while men displayed positive attitude towards family planning, women expressed negative attitude towards it. Similarly, a connection between religious affiliation and perception towards family planning was also explored; and it was discovered that while majority of the Christian population sampled expressed having positive attitude towards family planning methods, the majority of Muslim sampled population disagreed, most of them citing religious reasons (see table 9). The findings of the study also revealed that religion to an extent determines people attitude and knowledge of family planning. However, Oladeji \& Folaranmi (2007) provided further clarification on the connection between Islam and attitude towards Family planning when they explained that the Islamic doctrine of encouraging polygamy as a form of marriage effectively sanctions and legitimizes large family and in effect, frowns at practices that distorts or compromises this arrangement. In other words, the ideal teaching of Islam does not support family planning. The Muslim sampled population in Danmusa local government might appear to be uncertain probably because of the sensitivity of the question vis a vis Islamic doctrine. Also Azmat et al (2012) concluded that respondents in their study complained that although their role in family planning conflict with their moral, cultural and religious beliefs, modernity have made family planning a necessary evil in contemporary society.

The fourth objective is concern with identifying the major factors that influence attitude towards family planning practices. The findings as presented in table 8 revealed education to be one of the factors that determines attitude towards family planning in Danmusa local government area. To provide further empirical validation on this, a connection between educational level and attitude towards family planning was explored. The data from this (see table 10) revealed that level of education can also influence negative or positive attitude towards family planning. The findings revealed that high level of education illicit positive attitude towards family planning practices. Apav-Igba \& Ilim (2015) in an earlier study had submitted that high level of education equal positive attitude and perception towards family planning. The last objective of the study is to find out ways to encourage positive attitude towards family planning. Majority of the sampled population for study suggested that health workers in charge of delivering family planning services need to be trained on how choose to safe and effective family planning method for couples in the rural areas.

\section{Conclusion/ Recommendation}

The results of the study provide a greater understanding into the fact that the awareness regarding family planning has actually reached the people in the rural and semi-rural areas. The study suggests that their knowledge has been acquired fairly recently, usually through radio or television shows. However, most of them are only more comfortable with traditional and other methods they trust and are religiously permissive. Modern family planning methods like condoms and other contraceptive pills were not popular among the couples in Dan Musa. The extensive media campaigns in major towns across Katsina state in recent years have clearly reached a large part of the rural audience. However a source of concern is the fact that a significant number of people are yet to fully embrace and trust modern family planning methods. Also, among the sampled population, the men indicated more positive attitude towards family planning than 
women. Religion, level of education was also discovered to be key determinants of perception, knowledge and attitude towards family planning in Dan musa local government area of Katsina state. This implies that it is not just enough to provide contraceptives and other family planning services for the people in the rural areas; it must go hand in hand with formal education as well as orientation through religious leaders.

Some of the findings are contrary to conventional trend regarding family planning and child bearing among subSaharan Africans generally. First, our data reveal that the vast majority of men in Danmusa have positive attitude regarding family planning than women. This is contrary to the traditional expectations where women are known to first embrace family planning and contraceptive usage and in the process convince their partners and spouses to follow suit. A useful, and perhaps significant discovery; particularly to policy makers from the study is the fact that a lot of people considers knowledge of family method to be adopted as a primary determinant in considering which type to use. This implies that extensive education needs to be carried out regarding the potency, efficacy as well as prospects and challenges of each family planning methods.

\section{Recommendation}

Firstly, education has to be encouraged, since education improves people's knowledge and awareness of themselves with regards to making informed choices and decisions vis a vis health needs sex regulation and control hence child spacing.

Relatedly, health workers in charge of providing family planning services need to be trained and retrained on continuous bases to be up to date with the current and modern trends and methods of family planning to be able to provide effective family planning services to couple and partners. This will be achieved by way creating more family planning health centers in the community and organizing seminars, and workshop for both the beneficiaries and health workers for them to be acquainted with the improved technology.

Similarly, money should be made available annually for public campaigns and awareness in print and electronic media for the regarding the need for family planning and child spacing and the benefits this practice holds for individuals, groups and society.

Furthermore, men need to be encouraged to embrace and accept family planning methods and assist women to sustain the practice. Also more options for family planning needs to be introduced and the existing methods need to be further improved upon to reduce the side effects and on beneficiary's reproductive health.

\section{References}

i. Akinwalere, B.O; Owolabi, K.E; and Adesida, M.A; (2015). Perception and Utilization of Family Planning among Rural Farmers in Ondo State, Nigeria. In Asian Journal of Agricultural Extension, Economics\& Sociology 6(2): 8593, 2015. ISSN: 2320-7027

ii. Apavigba, L \& Ilim, M.M (2015). Socio-Cultural Factors Affecting Human Fertility in Nigeria. Yet to published paper undergoing peer review.

iii. Azmat, S. K; Ghulam, M; Waqas, H; Muhammad, A; Aftab, A; Mohsina, B; (2012). Barriers and perceptions regarding different contraceptives and family planning practices amongst men and women of reproductive age in rural Pakistan: a qualitative study in Pakistani Journal of Public Health. 2, (1), 2012.

iv. Chigozie, O. I; Precious, N. E; Uchenna, M. U; \& Godswill, A.N(2015).Comparative assessment of family planning knowledge and attitude of men in urban and rural areas of Anambra state, South-East of Nigeria. In Research Journal of Women's Health. ISSN 2054-9865. 2 (3).

v. Demographic Health Survey (2003). A country wide Survey 2003.

vi. Lutz, W. (2003). Future Reproductive Behaviour in Industrialised Countries. In Lutz (Ed.), The Future Population of the World. Luxemburg, Austria. International Institute of Applied System Analyses.

vii. Mkangi, K. (2001). The Social Cost of Smaller Nuclear Families: Critique of Demographic Transition. (Occasional Papers from Summary Series B). Development Studies.

viii. National AIDS and Reproductive Health Survey (NARHS) (2012). Sub-Saharan Second Quarter Report 2012.

ix. Ofonime, J; and Ekong,I; (2015). Knowledge, Attitude and Practice of Family Planning among Women in a Rural Community in Southern Nigeria. In British Journal of Medicine \& Medical Research 12(2).

x. Olaitan, O.L; (2012). Factors influencing the choice of family planning among couples in Southwest Nigeria. In international Journal of Medicine and Medical Sciences. 3(7). Available online http:/ / www.academicjournals.org/ ijmms ISSN 2006-9723 @2011 Academic Journals.

xi. Oladeji, O \& Folaranmi, O (2007). Socio-cultural factors Influencing Family Planning among couples in Ibadan Metropolis. In Pakistani Journal of Social Sciences, 4 (3). Medwell Journals.

xii. Omishakin, M. Y.J, (2015). Knowledge, Attitude and Practice of Family Planning among Healthcare Providers in Two Selected Health Centres in Osogbo Local Government, Osun State. In Case Report Women's Health \& Gynecology. ISSN: 2369-307. www.scientonline.org Womens Health GynecolVolume. 1(2).

xiii. Sulaiman, K.O; (2011). An Assessment of Muslims 'Reactions to The Immunization of Children in Northern Nigeria. In Medical Journal of Islamic World Academy of Sciences 2014; 22(3): $\quad$ 123-132.

xiv. United Nations Population Department (2012). Report on Population trend in Nigeria.

xv. World Bank. (2002). World development report 2010: Development and climate change. Washington: The World Bank.

xvi. World Bank. (2013). Turn down the heat: climate extremes, regional impacts, and the case for resilience. Washington D.C.:The World Bank. 